\title{
POLA ASUH PENDIDIKAN PESANTREN TERHADAP PERKEMBANGAN AFEKTIF ANAK DI PONDOK PESANTREN AL QOHHARIYAH KABUPATEN BOGOR
}

\author{
PESANTREN EDUCATION UPDATE PATTERNS ON CHILDREN'S AFFECTIVE \\ DEVELOPMENT AT AL-QOHHARIYAH ISLAMIC BOARDING SCHOOL BOGOR \\ REGENCY
}

Bakti Toni Endaryono, Qowaid, Robihudin

IAI Nasional Laa Roiba Bogor

email: baktitoni@gmail.com

Naskah Diterima: 21 Maret 2020; Direvisi: 25 Agustus 2020; Disetujui: 6 Desember 2020

\begin{abstract}
Education in pesantren is generally carried out in a dormitory that lives and stays for 24 hours, under the main guidance of the Kiai or the head of the pesantren. It is necessary to understand the parenting patterns of children in the pesantren so that the conditions and affective development of children are created as expected by parents who submit their children to study at the pesantren. This study aims to understand the parenting style of pesantren education on children's affective development. This study used a qualitative method with a case study approach. The data collection technique is done by interview, observation, and document review. The results showed that the boarding school's education parenting towards children's affective development was manifested through the cultivation of santri discipline, cultivation of independence, cultivation of an awareness of the importance of society, habituation of conducting book studies, developing talents and interests, and giving sanctions to students who violate the discipline. This finding reinforces the opinion that pesantren have played a role in educating people's lives. It is suggested that this parenting style be studied more widely and deeply so that it can then be applied to other pesantren.
\end{abstract}

Keywords: Parenting pattern; Education; Child affective development; Islamic Boarding school

\begin{abstract}
Abstrak
Pendidikan di pesantren umumnya dilaksanakan dalam suatu asrama yang hidup dan tinggal selama 24 jam, di bawah bimbingan utama kiai atau pimpinan pondok pesantren. Diperlukan pemahaman pola pengasuhan anak di pesantren sehingga tercipta kondisi dan perkembangan afektif anak sesuai yang diharapkan oleh orang tua yang menyerahkan anaknya belajar di pesantren. Penelitian ini bertujuan untuk memahami pola asuh pendidikan pesantren terhadap perkembangam afektif anak. Dalam penelitian ini digunakan metode kualitatif dengan pendekatan studi kasus. Teknik pemgumpulan data dilakukan dengan wawancara, observasi dan telaah dokumen. Hasil penelitian menunjukkan bahwa pola asuh pendidikan pesantren terhadap perkembangan afektif anak terwujud melalui penanaman disiplin santri, penanaman kemandirian, penanaman sikap sadar akan pentingnya bermasyarakat, pembiasaan melakukan kajian kitab, pengembangan bakat dan minat, serta pemberian sangsi terhadap santri yang melanggar tata tertib. Temuan ini menguatkan pendapat bahwa pesantren telah berperan dalam mencerdaskan kehidupan masyarakat. Oleh karena itu disarankan agar pola asuh tersebut dikaji lebih luas dan mendalam untuk kemudian dapat diterapkan pada pesantren lainnya.
\end{abstract}

Kata kunci: Pola asuh; Pendidikan; Perkembangan afektif anak; Pesantren 


\section{PENDAHULUAN}

Pendidikan merupakan elemen yang sangat penting dalam kehidupan, karena dari sepanjang perjalanan manusia, pendidikan merupakan barometer untuk mencapai sebuah nilai-nilai kehidupan. Pendidikan adalah proses utama kemajuan suatu peradaban. Semakin baik mutu pendidikan maka akan pesat kemajuan sebuah peradaban, begitu pula sebaliknya. Untuk menunjukkan betapa pentingnya pendidikan, Tilaar (1999) mengatakan bahwa tidak ada suatu masyarakat pun yang dapat eksis tanpa pendidikan. Pendidikan tidak dapat dikucilkan dari proses pemanusiaan.

Dalam Islam, posisi pendidikan sangat penting. Hal ini dapat dilihat, baik dari landasan Al Qur'an, hadits, maupun sejarah perjalanan Islam itu sendiri dari awal kedatangan Islam sampai saat ini. Dalam Al Qur'an, sebagimana terdapat dalam Surat Al Mujadalah ayat 11, dikatakan bahwa Allah akan mengangkat harkat derajat orang yang beriman dan berilmu. Dalam Islam pendidikan tidak hanya dipandang dalam batas bangku sekolah atau kuliah semata, akan tetapi pandangan Islam jauh lebih luas yaitu pendidikan sepanjang hayat, karena memang itulah yang diajarkan oleh Rosulullah SAW. Beliau meminta kita untuk mencari ilmu dari sejak lahir sampai mati.

Menurut Islam, pendidikan bukan hanya berisi pendidikan umum untuk kepentingan kehidupan di dunia ini saja, akan tetapi pendidikan juga untuk kepentingan kehidupan setelah manusia meninggalkan dunia ini, yang dikenal dengan kehidupan di akhirat nanti. Seorang muslim tidak cukup memberikan pendidikan yang bersifat keduniaan saja atau dengan kata lain pendidikan umum saja. Pendidikan agama pun juga dipentingkan. Manusia hidup di muka bumi ini tidak cukup hanya menggunakan intelektualnya saja (kecerdasan otak semata), tetapi juga harus disempurnakan dengan aspek spiritual (kecerdasan dari dalam hati). Maka dari itu, untuk menyeimbangkan pendidikan anak, orang tua bukan hanya memasukan anak ke pendidikan sekolah saja. Seorang anak mesti belajar ke lembaga pendidikan yang bersifat keagamaan, seperti madrasah, pondok pesantren, majlis ta'lim dan lain-lain. Rosulullah SAW bersabda dalam sebuah hadits yang maksudnya adalah bukanlah sebaik-baik muslim apabila meninggalkan perkara dunia hanya untuk mementingkan akhirat, dan bukan pula sebaik-baik muslim apabila meninggalkan perkara akhirat hanya untuk kepentingan dunia. Sesungguhnya dunia adalah jembatan untuk menggapai akhirat.

Agar mendalami sekaligus mempraktekkan kehidupan keislaman bagi anak, maka banyak orang tua yang menyerahkan anak-anaknya untuk dididik di pondok pesantren. Sebab, pesantren memiliki banyak fungsi. Salah satu fungsi penting pondok pesantren adalah fuSngsi pendidikan. Disamping itu, pesantren juga memiliki fungsi dakwah dan pengembangan masyarakat. (Undang-Undang No 18 Tahun 2019 Pasal 4 Tentang Pesantren). Sebagai lembaga pendidikan Islam tertua di Indonesia, pesantren memiliki konstribusi penting dalam mencerdaskan kehidupan bangsa (Madjid, 1983). Pesantren adalah sebuah kehidupan yang unik. Dengan pola kehidupannya yang unik tersebut, pesantren mampu bertahan selama berabad-abad (Wahid, 1983).

Pendidikan pesantren sangat bervariasi dan beragam, sebagaimana yang terdapat pada sekolah misalnya. Dalam beberapa tahun terakhir, pondok pesantren mengalami perkembangan pesat dan mengesankan, baik secara kuantitas maupun secara kualitas. Kemajuan tersebut tidak dilepaskan dari adanya perubahan lingkungan strategis yang terjadi baik pada tingkat lokal, nasional, maupun global. Sehingga adalah wajar apabila saat ini juga banyak lembaga pendidikan menyelenggarakan pendidikan dengan mengacu pada pesantren, walau tidak sepenuhnya, seperti sekolah Islam terpadu (Qowaid, 2017, 2019).

Sebagian besar pondok pesantren mewajibkan santrinya untuk tinggal (mukim) di asrama atau pondok. Mereka dididik di asrama selama 24 jam penuh. Mulai bangun tidur di pagi hari sampai malam saat akan dan selama tidur malam. Oleh karena itu, pengasuhan terhadap santri menempati posisi penting dalam proses pendidikan di pondok pesantren. Sementara itu, santri masih berusia muda, yang jauh dari orang tua atau walinya. Mereka perlu dibimbing, dan memang tujuan utama masuk 
pondok pesantren adalah untuk dibimbing (Sunarto \& Hartono, 2008).

Di pondok pesantren mereka dididik pendidikan dan pengajaran melalui kegiatan intra dan ekstra kurikuler. Di samping itu, dilakukan pula pemberian contoh kepada santri (baik berupa tingkah laku, sifat, sikap, maupun cara berfikir), pemberian penghargaan, motivasi, pemberian hukuman, dan pembujukan. Penghargaannya berupa pemberian hadiah dan pujian, sedangkan hukumannya berupa sangsi yang diberikan sebagai wujud atau akibat dari ulah dan perbuatan melanggar aturan yang berlaku. Bentuknya mulai dari hukuman ringan (nasihat) sampai berat (dikeluarkan dari pesantren). Pembujukan dilakukan dengan memberi nasihat melalui pendekatan secara perorangan untuk membantu santri dalam memecahkan masalahnya. Nasihat yang lemah lembut diharapkan untuk mengembalikan santri pada jalanya yang benar. (Rakhmawati, 2013).

Pola asuh para pimpinan pondok pesantren tersebut akan mempengaruhi perkembangan afektif anak atau santri. Mengingat pentingnya pola asuh anak dalam pesantren terhadap perkembangan afektif anak, maka dilakukanlah penelitian tentang pola asuh anak di salah satu pesantren. Artikel ini difokuskan kepada pola asuh pesntren terhadap perkembangan afektif anak di Pesantren Al Qohhariyah Kabupaten Bogor. Masalahnya adalah seperti apakah pola asuh anak terhadap perkembangan afektif anak di Pesantren Al Qohhariyah tersebut? Bagaimana pula sejarah perkembangan dan kondisi pondok pesantren yang menjadi tempat pendidikan anak atau santri tersebut?

Tujuan tulisan ini adalah untuk memahami pola asuh terhadap perkembangan afektif anak di Pesantren Al Qohhariyah. Di samping itu, penelitian ini juga dimaksudkan mengetahui sejarah perkembangan dan kondisi Pondok Pesantren Al Qohhariyah di Kabupaten Bogor tersebut.

\section{KAJIAN TEORI}

Pengasuhan anak adalah salah satu bagian penting dalam proses sosialisasi. Menurut Sunarti dkk (1989), pengasuhan anak dalam suatu masyarakat berarti suatu cara dalam mempersiapkan seseorang menjadi anggota masyarakat. Artinya mempersiapkan orang itu dimaksudkan untuk dapat bertingkahlaku sesuai dengan dan berpedoman pada kebudayaan yang didukungnya. Dengan demikian pengasuhan anak yang merupakan bagian dari sosialisasi pada dasarnya berfungsi untuk mempertahankan kebudayan dalam suatu masyarakat tertentu.

Sementara itu, menurut Thoha (1996), pola asuh orang tua adalah cara terbaik yang ditempuh oleh orang tua dalam mendidik anak sebagai perwujudan dari tanggung jawab kepada anak. (Thoha, 1996). Sedangkan menurut Gunarsa, pola asuh orang tua adalah sikap dan cara orang tua dalam mempersiapkan anggota keluarga yang lebih muda termasuk anak supaya dapat mengambil keputusan sendiri dan bertindak sendiri sehingga mengalami perubahan dari keadaan bergantung kepada orang tua menjadi berdiri sendiri dan bertanggung jawab sendiri (Gunarsa, 2007). Dengan demikian yang dimaksud dengan pola asuh pendidikan di pesantren adalah cara terbaik pimpinan pesantren mempersiapkan santri untuk mampu mengambil keputusan sendiri dan bertanggungjawab.

Pemberian disiplin dalam arti mengajarkan aturan-aturan bertujuan supaya seseorang dapat menyesuaikan diri dalam lingkungannya sehingga menghasilkan sikap yang baik. Dengan demikian cara atau bentuk disiplin yang diberikan, banyak tergantung pada pemberi disiplin, yaitu orang tua atau tokoh otoritas lainnya. Orang tua dan atau wali anak mempunyai pengaruh penting. Cara pemberian disiplin berbeda-beda dan sudah barang tentu memberikan hasil yang berbeda, termasuk prestasi yang diraihnya (Soekamto, 1999).

Penanaman nilai-nilai yang diberikan tentunya tidak bisa dilakukan dalam sekejab, hal ini memerlukan suatu proses yaitu dengan sosialisasi. Menurut Soekanto (1986), sosialisasi adalah suatu proses dimana warga masyarakat dididik untuk mengenal, memahami, mentaati, menghargai dan menghayati norma-norma dan nilai-nilai yang berlaku di masyarakat. Lebih lanjut, proses sosialisasi tersebut tersirat ke dalam beberapa tahap kegiatan. Khaerudin (1985) membagi ke dalam tiga tahap, yakni tahap belajar, tahap 
penyesuaian diri terhadap lingkungan, dan tahap pengalaman mental. Dalam tahap belajar sosialisasi berlangsung dan individu mengalami proses belajar. Dalam tahap penyesuaian diri terhadap lingkungan, individu tidak begitu saja melakukan tindakan yang dianggap sesuai dengan dirinya karena individu memiliki lingkungan di luar baik lingkungan fisik maupun lingkungan sosial. Sedangkan pada tahap pengalaman mental, pengalaman seseorang akan membentuk suatu sikap pada diri seseorang, didahului oleh suatu kebiasaan yang menimbulkan reaksi sama terhadap masalah yang sama.

Pada prinsipnya cara pengasuhan anak ini setidak-tidaknya mengandung sifat penggajaran, dan pembujukan (Rakhmawati, 2013). Penggajaran disini diartikan sebagai cara mensosialisasikan nilai-nilai, norma, larangan, keharusan yang harus ditaati dan diketahui anak, dan juga pendidikan (moral maupun intelektual), penerapan disiplin. Pengganjaran dalam pola pengasuhan dapat dibedakan menjadi 2 jenis, yaitu hukuman dan penghargaan. Hukuman berarti menjatuhkan sangsi pada seseorang karena suatu kesalahan, perlawanan atau pelanggaran sebagai ganjaran atau pembalasan. Penghargaan berarti tiap bentuk penghormatan untuk setiap hasil yang baik. Penghargaan tidak harus dalam bentuk materi, tetapi dapat berupa kata-kata pujian, senyuman atau tepukan di punggung.

Pemahaman tentang kekerasan lebih ditentukan pada segi akibat atau pengaruhnya pada manusia. Pemahaman ini tidak membedakan tindakan-tindakan yang keras, (keras sebagai sifat) dengan tindakan-tindakan kekerasan. Beberapa dimensi penting dari kekerasan diuraikan oleh Santoso (2002).

Pertama adala kekerasan fisik dan psikologis. Dalam kekerasan fisik, tubuh manusia disakiti secara jasmani bahkan sampai pada pembunuhan.Sedangkan kekerasan psikologis adalah tekanan yang dimaksudkan meredusir kemampuan mental atau otak. Kedua adalah adanya pengaruh positif dan negatif. Dalam sistem orientasi imbalan (reward oriented), sebenarnya terdapat "pengendalian", tidak bebas, kurang terbuka, dan cenderung manipulatif, meskipun memberikan kenikmatan dan euphoria.
Dimensi ketiga adalah ada obyek atau tidak. Dalam tindakan tertentu tetap terdapat ancaman kekerasan fisik dan psikologis, meskipun tidak memakan korban, akan tetapi membatasi tindakan manusia. Dimensi keempat adalah kekerasan langsung dan tidak langsung. Kekerasan disebut langsung atau personal jika ada pelakunya, dan bila tidak ada pelakunya disebut tidak langsung. Kekerasan tidak langsung sudah menjadi bagian struktur yang tidak baik dan menampakkan diri sebagai kekuasaan tidak seimbang yang menyebabkan peluang hidup tidak sama. Dimensi kelima adalah disengaja atau tidak. Bertitikberat pada akibat dan bukan tujuan pemahaman, yang hanya menekankan unsur sengaja tentu tidak cukup untuk melihat dan mengatasi kekerasan struktural yang bekerja secara halus dan tidak disengaja. Dari sudut korban, sengaja atau tidak, kekerasan tetap kekerasan.

Dimensi keenam adalah aspek yang tampak dan tersembunyi. Kekerasan yang tampak, nyata (manifest), baik yang personal maupun struktural, dapat dilihat meski secara tidak langsung. Sedangkan kekerasan tersembunyi adalah sesuatu yang memang tidak kelihatan (latent), tetapi bisa dengan mudah meledak. Kekerasan tersembunyi akan terjadi jika situasi menjadi begitu tidak stabil sehingga tingkat realisasi aktual dapat menurun dengan mudah. Kekerasan tersembunyi yang struktural terjadi jika suatu struktur egaliter dapat dengan mudah diubah menjadi feodal, atau evolusi hasil dukungan militer yang hirarkis dapat berubah lagi menjadi struktur hirarkis setelah tantangan utama terlewati.

Pembujukan dilakukan agar anak mau mengikuti ajakan atau perintah pengasuh dengan kata-kata yang lebih halus, menarik hati dan terkesan tidak menyuruh. Hal itu dimaksudkan agar anak mengiktui ajakan pengasuh.

Adapun pendidikan telah didefinisikan secara berbeda-beda oleh berbagai tokoh. Namun semua itu bersifat saling melengkapi. Hal ini dapat dikihat dari beberapa uraian tokoh. Pendapat Hasan Basri (2013) misalnya tidak mesti sama dengan beberapa pendapat tokoh lainnya seperti Ahmad Tafsir (1992), Muhaimin dkk (2001), Daulay (2004), Langgulung (2003) dan lain sebagainya. Dengan merangkum pandangan yang berbeda, Azra (2002), 
menyimpulkan bahwa pendidikan merupakan suatu proses penyiapan generasi muda untuk menjalankan kehidupan memenuhi tujuan hidupnya secara lebih efektif dan efisien. Agama Islam sangat mengutamakan proses pendidikan, hal tersebut dapat dilihat dari lima ayat yang pertama kali diturunkan kepada Nabi Muhammad SAW dalam surat al 'Alaq. Banyak juga hadits yang menjelaskan tentang pentingnya pendidikan bagi manusia.

Adapun pesantren sebagai salah satu lembaga pendidikan yang sering disebut juga pondok pesantren berasal dari kata "santri" kata ini mempunyai dua pengertian, yaitu (1) orang yang beribadat dengan sungguh-sungguh; orang sholeh. (2) orang yang mendalami pengajiannya dalam agama Islam dengan berguru ke tempat yang jauh seperti pesantren dal lain sebagainya. Dalam Enslikopedia Islam juga dikatakan bahwa kata pesantren atau santri berasal dari bahasa Tamil yang berarti Guru Mengaji. Sumber lain menyebutkan bahwa kata ini berasal dari bahasa India Shartri dari kata Sharta yang berarti buku-buku tentang ilmu pengetahuan (Departemen Agama RI., 2003).

Mastuhu (1994) mengidentifikasi unsurunsur sistem pendidikan pesantren dalam beberapa kelompok. Unsurnya adalah a) aktor atau pelaku: kyai, ustadz, santri, pengurus; b) sarana perangkat keras: masjid, rumah kyai dan ustadz, asrama santri, gedung sekolah atau madrasah, tanah, dan sarana lainnya; c) sarana perangkat lunak: tujuan, kurikulum, kitab, penilaian, tata tertib, perpustakaan, pusat dokumentasi dan penerangan, cara pengajaran, pusat pengembangan masyarakat, dan alat-alat pendidikan lainnya.

Secara umum konsep perkembangan dikemukakan oleh Sunarto dan Ny. B. Agung Hartono (2008) sebagai berikut: "Perkembangan sejalan dengan prinsip orthogenetis, bahwa perkembangan berlangsung dari keadaan global dan kurang berdiferensiasi sampai keadaan dimana diferensiasi, artikulasi dan integrasi meningkat secara bertahap". Proses diferensiasi itu diartikan sebagai prinsip totalitas pada diri anak; bahwa dari penghayatan totalitas itu lambat laun bagian-bagiannya menjadi semakin nyata dan bertambah jelas dalam kerangka keseluruhan. Sedangkan afektif mencakup ranah emosional, sikap, nilai dan moral. Jadi dari uraian diatas dapat diartikan bahwa perkembangan afektif adalah suatu perubahan dari segi psikologis manusia yang meliputi emosi, nilai, sikap, moral dan yang lainya.

Afeksi adalah materi yang berdasarkan segala sesuatu yang berkaitan dengan emosi seperti penghargaan, nilai, perasaan, semangat, minat, dan sikap terhadap sesuatu hal. Pada ranah afeksi, Bloom menyusun pembagian kategorinya dengan David Krathwol yaitu: penerimaan, responsive, penilaian, organisasi dan karakterisasi, sebagaimana dikutip oleh Monty P. Satiadarma and Fidelis E. Waruwu (2003).

Perkembangan afektif anak adalah perkembangan yang dapat dilihat dari perubahan emosi anak melalui perilaku dan tingkah laku anak dimana perubahan emosi pada anak dapat dilihat dari dalam diri individu tentang keadaan mental dan fisik dan berwujud suatu tingkah laku yang tampak (Astrea, N. 2019). Untuk memahami tingkat kematangan afektif anak orang tua dan guru dapat memanfaatkan pengetahuan tentang enam tahapan perkembangan afektif yang seharusnya dilalui oleh setiap anak yang normal. Pada tiap tahap pengalaman emosional yang sesuai merupakan dasar bagi berbagai kemampuan anak meliputi kemampuan emosional, sosial, kognitif, ketrampilan, bahasa serta konsep dirinya di masa depan. Harus diingat bahwa tahapan-tahapan tersebut berlangsung secara berkesinambungan (Dianwinarti, 2012).

Pondok pesantren juga sangat mendukung perkembangan afektif anak, seperti emosi, nilai, moral dan sikap. Perasaan atau prilaku kita sehari-hari pada umumnya disertai oleh perasaan-perasaan tertentu, seperti perasaan senang atau tidak senang yang menyertai perbuatan-perbuatan kita sehari-hari yang disebut dengan warna afektif. Bila warna afektif tersebut kuat, maka perasaan-perasaan menjadi lebih mendalam, lebih luas, dan lebih terarah. Perasaan-perasaan seperti ini disebut emosi (Sarlito, 1982). Pengaruh pondok pesantren sangat besar terhadap perkembangan emosi, nilai, moral dan sikap anak, karena di lingkungan pesantren para santri merasakan suasana yang tidak sama seperti di rumah. Di pesantren terdapat disiplin yang ketat selama 24 jam. Hal tersebut secara tidak langsung melatih 
emosi, nilai, moral dan sikap para santri sekaligus melatih kesabaran dan tanggung jawab para santri dari segi mental (Rakhmat, 2011).

Adapun upaya-upaya lain yang dapat dilakukan dalam mengembangkan afektif anak adalah menurut menurut Femi Olivia (2007) mencakup penciptaan komunikasi, yang baik dan penciptaan iklim lingkungan yang serasi. Berikut uraian lebih lanjut yang disesuaikan dengan kondisi di pesantren.

Di pesantren para santri hendaknya diberi kesempatan berpartisipasi untuk mengembangkan aspek afektif, misalnya dalam kerja kelompok/musyawarah dalam membahas suatu kitab ta'limul muhadasah (belajar berbicara) pada kegiatan muhadhoroh. Sehingga mereka lebih aktif tidak hanya sebagai pendengar, tetapi juga sebagai pembicara. Dengan demikian secara perlahan apabila santri terbiasa diberikan kesempatan untuk aktip berpartisipasi dalam berbagai macam kegiatan maka akan timbul keberanian yang positif pada diri santri untuk mengembangkan potensi pada seorang anak. Para ahli yang mengikuti aliran sosilogis menganggap bahwa perkembangan adalah proses sosialisasi. Anak manusia mulamula bersifat a-sosial (barang kali untuk tempatnya dapat disebut prasosial) yang kemudian dalam perkembangannya sedikit demi sedikit disosialisasikan. Salah seorang ahli yang mempunyai konsepsi yang demikian itu yang cukup terkenal dan besar pengaruhnya adalah Jamer Mark Baldwin (1864-1934). Dengan demikian dapat kita pahami betapa pentingnya hidup bersosialisasi begitupun agama Islam yang menjunjung tinggi sosialisasi. Bahkan dikatan bahwa sosialisasi agama tidak menayakan hakekat agama, melainkan menyelidiki tempat agama dan penganutannya oleh masyarakat, didalm kehidupan sosial (Bukhori, Umar, 2011).

Para santri sering bersikap kritis, menentang nilai-nilai dan dasar-dasar hidup orang di sekitarnya seperti orang tua dan santri dewasa. Karena itu, orang tua dan kiyai serta santri dewasa lainnya perlu memberi contoh perilaku yang merupakan perwujudan nilainilai yang diperjuangkan. Untuk santri, moral merupakan kebutuhan tersendiri karena seorang santri sedang membutuhkan pedoman dalam menemukan jati diri. Oleh karen itulah, nilai- nilai keagamaan sangatlah penting karena agama juga mengajarkan tingkah laku yang baik dan buruk yang semua ini jelas sangat kental didapati di pesantren. Kita sadari bahwa berbicara melalui tingkah laku itu lebih baik dari pada berbicara melalui ucapan.

Oleh karena itu dibutuhkan prinsip yang konsisten dan komitmen yang kuat yang dimiliki oleh para pendidik dalam menegakkan suri tauladan bagi seorang yang dididik. Para psikolog memiliki pemahaman yang mendalam berkenaan kekuatan prinsip konsistensi dalam mengarahkan tindakan manusia. Theoretikus terkenal seperti Leon Festiner, Fritz Hieder, dan Theodore Newcomb berpendapat bahwa keinginan untuk konsisten merupakan pusat motivator tingkah laku kita untuk memahami mengapa konsistensi dapat menjadi sebuah motif yang sangat kuat. Konsistensi adalah suatu sikap yang dihargai dan diakui dalam kebanyakan situasi. Dan ketidakkonsistenan biasanya dianggap sebagai suatu karakter personal yang buruk. Orang yang ucapannya, keyakinannya, dan janjinya saling bertentangan akan dianggap sebagai orang yang tidak mampu, bingung, bermuka dua, bahkan sakit jiwa. Sebaiknya konsistensi seorang pendidik yang tinggi sering kali diasosiakan dengan kekuatan personal dan intelektual. Karena itu jelaslah bahwa konsistensi personal yang baik sangat dihargai dalam kebudayaan kita. Sikap tersebut memberikan kepada kita orientasi terhadap dunia yang menguntungka dan rasional (Cialdini, 2005).

\section{METODOLOGI}

Dalam penelitian ini digunakan pendekatan kualitatif. Penelitian kualitatif ini lebih bersifat deskriptif, dengan proses dan makna dalam perspektif subjek lebih ditonjolkan. Jenis penelitiannya adalah studi kasus (case study) dengan rancangan single case study (studi kasus tunggal), suatu penelitian yang arah penelitiannya terpusat pada satu kasus atau satu fenomena saja, yakni fenomena yang terjadi pada pola asuh terhadap perkembangan afektif anak di Pondok Pesantren Al Qohhariyah Bogor. Alasan digunakan studi kasus ini karena riset studi kasus memungkinkan peneliti mengumpulkan informasi yang detil tentang pola asuh pendidikan pesantren tersebut. 
Penelitian lapangan dilaksanakan mulai tanggal 15 September sampai 30 September 2019. Sesudah itu, dilaksanakan tahapantahapan berikutnya sampai 03 Februari 2020. Teknik pengumpulan data yang digunakan dalam penelitian ini adalah wawancara, observasi, dan dokumentasi. Wawancara dilakukan dengan berhadapan secara langsung dengan yang diwawancarai dan juga diberikan daftar pertanyaan terlebih dahulu untuk dijawab pada kesempatan lain. Jenis wawancara yang digunakan dalam penelitian ini adalah wawancara mendalam (in-depth interview). Observasi dilakukan saat peneliti terjun langsung ke pesantren. Hasil observasi dan wawancara, dilengkapi dengan berbagai dokumen. Dokumen yang ada berupa tulisan, gambar atau foto, dan lain sebagainya.

Dalam penelitian ini, terdapat beberapa informan yang menjadi sumber informasi, antara lain adalah Kiai KH. Zainal Abidin S.Pd yang menjabat sebagai pengasuh Pondok Pesaantren, Ustaz Helmi Firdaus yang menjabat sebagai pengajar kitab Fiqih, Ustadz Elis Tsamrotul Aeni sebagai pengajar yang menjabat sebagai ketua Rois dan sekaligus sebagai putri Kiai. Berbagai dokumen yang terdapat di pesantren ini juga dijadikan bahan dalam artikel ini. Diantaranya adalah profil pondok pesantren yang dikelola oleh Rois yang terupdate di link http://m.facebook.com/Anasantris/ .

Teknik analisis data yang digunakan dalam penelitian ini adalah analisis data model Miles dan Huberman (dalam Sugiyono, 2011: 246). Analisis data dilakukan pada saat dan sesudah pengumpulan data. Alur penting yang kedua dari analisis data adalah penyajian data. Dengan melihat penyajian-penyajian tersebut, maka dapat dipahami apa yang sedang terjadi dan apa yang harus dilakukan lebih jauh dalam menganalisis ataukah mengambil tindakan berdasarkan pemahaman dari penyajianpenyajian tersebut (Wahidmurni, 2008).

\section{HASIL DAN PEMBAHASAN}

\section{Asal Usul dan Perkembangan Pesantren Al- Qohhariyah}

Pondok Pesantren Al-Qohhariyah merupakan lembaga pendidikan yang didirikan pada tahun 1989 oleh KH. Zainal Abidin S.Pd dan berlokasi di kampung Pasir Datar, Desa Cibening, Kecamatan Pamijahan Kabupaten Bogor. Ada beberapa alasan sehingga dinamakan Pondok Pesantren Al-Qohhariyah. Menurut Ustadz Elis Tsamrotul Aeni (pengajar dan putri Kiai Zainal Abidin), sebutan AlQohhariyah itu sebetulnya diambil dari nama ayahanda KH. Zainal Abidin yaitu KH. Abdul Qohhar. Jadi nama tersebut dipakai sebagai penghormatan atas jasa ayahanda pendidiri pesantren. Selain itu, kata Al-Qohhariyah dilihat dari maknanya. Kata Al-Qohhariyah diambil dari Bahasa Arab yang juga merupakan salah satu asma Allah yang berjumlah 99 (Asmaul Husna) tersebut, yang artinya memaksa. Berkaitan dengan makna tersebut maka setiap santri yang mulai menetap dan belajar di pondok pesantren Al-Qohhariyah mesti menerima aturan yang ditetapkan di pondok Pesantren Al-Qohhariyah. (Aeni, 2019)

Menurut Kiai Zainal Abidin, Pimpinan Pesantren saat ini, aturan yang diterapkan disini tentunya memiliki tujuan yang baik dan masih dalam batas kewajaran atau tidak melanggar hukum yang berlaku, baik hukum agama ataupun hukum Negara. Aturan tersebut bersifat memaksa para santri untuk ditaati. Adapun aturan yang merupakan paksaan tersebut mencakup: paksaan untuk menjadi orang yang bermanfaat, paksaan untuk memiliki ilmu, dan paksaan menjadi manusia yang lebih baik. Setiap manusia yag dilahirkan ke muka bumi ini tentu tidak sepantasnya hanya menjadi benalu yang hidup jauh dari kemanfaatan, Rosulullah SAW bersabda yang artinya : "Sebaik baiknya manusia adalah bermanfaat bagi manusia lainnya". Ketika manusia menyadari fitrahnya sebagai manusia maka dia akan sadar bagaimana fungsinya hidup di muka bumi ini. Setiap manusia harus bisa memberi kemanfaatan, baik bagi dirinya sendiri, bagi orang lain ataupun bagi alam. (Abidin, 2019).

Adapun uraian tentang perkembangan Pondok Pesantren Al-Qohhariyah, disajikan mengenai perkembangan jumlah santri dan pembangunan fisik. Apabila dilihat dari jumlahnya, santri dari tahun ke tahun mengalami peningkatan walaupun peningkatannya tidak terlalu signifikan. Santri yang berdatanganpun bukan hanya dari daerah 
kabupaten Bogor saja, tetapi juga dari berbagai kabupaten dan kota, khususnya, di Provinsi Jawa Barat. Saat ini terdapat 153 orang santri. Dari keseluruhan santri diatas, untuk memudahkan kiyai dan para ustadz memberikan kajian kepada para santrinya, kiyai pun mengklasifikasikan dari seluruh santri menjadi tiga tingkatan, yakni Mubtadi (kelas dasar), Mutawasit (kelas pertengahan), dan Muntahi atau kelas atas (Komaruddin, 2019).

Apabila dilihat dari perkembangan pembangunan fisiknya, Pondok Pesantren AlQohhariyah mengalami peningkatan pula. Peningkatan pembangunan ini seiring dengan kebutuhan jumlah santri yang mengalami peningkatan dari waktu ke waktu dan juga peningkatan berbagai kegiatan yang ada di Pondok Pesantren Al-Qohhariyah. Adapun pembangunan yang dikembangkan di Pondok Pesantren Al-Qohhariyah diantaranya adalah penambahan lokal kobong/asrama, pembangunan aula tempat belajar mengajar santri, pembangunan dapur umum, pembangunan tempat mandi, cuci, dan kencing, pembangunan sanggar seni (tempat latihan berbagai macam kesenian), dan pembangunan area parkir.

Menurut Ustadz Helmi Firdaus, semua yang ada di dalam pondok ini merupakan ilmu. Apa yang dikatakan, atau diucapkan, atau kerjakan itu adalah ilmu bagi warga pondok pesantren. Ilmu merupakan faktor yang sangat penting yang harus ada di dalam mengarungi kehidupan ini. Sebab apabila manusia hidup tanpa didasari dengan ilmu maka manusia akan sesat, tidak dapat membedakan mana yang baik dan mana yang tidak baik, mana yang hak dan mana yang batil, mana jalan yang sepantasnya dilalui dan mana jalan yang harus dihindari. Apabila manusia menjalani kehidupan ini dengan ilmu maka manusia akan dijauhkan dari kesesatan dunia dan akherat, bahkan ketika nabi Sulaiman diberi 3 pilihan oleh Allah SWT untuk memilih satu antara ilmu, harta dan kerajaan maka nabi Sulaiman memilih ilmu. Maka diharapkan, setelah seorang santri masuk ke Pesantren Al-Qohhariyah maka yang sebelumnya bertingkahlaku tidak baik pada akhirnya harus menjadi lebih baik, melalui kajian dan disiplin yang diterapkan di Pesantren Al-Qohhariyah tersebut. (Firdaus, 2019).

\section{Pola Asuh Pendidikan Pesantren Terhadap Perkembangan Afektif Anak}

Sebagaimana diuraikan di muka, yang dimaksud dengan pola asuh pendidikan di pesantren pada dasarnya adalah cara terbaik pimpinan pesantren mempersiapkan santri untuk mampu mengambil keputusan sendiri dan bertanggungjawab. Pola Asuh Pendidikan Pondok Pesantren Al-Qohhariyah terwujud melalui sikap disiplin yang tinggi, dibiasakan untuk berani tampil di hadapan umum, dibiasakan hidup mandiri, pengembangan bakat dan minat seperti kesenian Islam marawis, qosidah, hadroh, futsal dan silat. Di samping itu di pesantren juga ditetapkan adanya tata tertib dan sangsi sebagai upaya yang ditanamkan pondok pesantren Al-Qohhariyah untuk mengembangkan kematangan emosi anak. Setelah dilakukan berbagai macam kegiatan yang telah dilakukan oleh pondok pesantren AlQohhariyah, terdapat sejumlah perubahan yang baik bagi perkembangan santri.

Berikut diuraikan secara lebih rinci pola asuh pendidikan pesantren terhadap perkembangan afektif anak, yang mencakup penanaman disiplin santri, pembiasaan melakukan kajian kitab, penanaman kemandirian, pemberian sangsi terhadap santri yang melanggar tata tertib, penanaman sikap sadar akan pentingnya bermasyarakat, dan pengembangan bakat dan minat.

Penanaman disiplin yang tinggi, menuntut anak untuk lebih gesit dan giat dalam melaksanakan segala sesuatu sesuai dengan waktu dan tatanan yang berlaku. Mulanya ketika santri datang ke Pondok Pesantren AlQohhariyah bermalas-malasan, tidak disiplin akan waktu, karena terbiasa dengan kebebasan kehidupan di rumah dan di lingkungan teman temannya. Lama kelamaan santri terbiasa dengan disiplin yang telah ditetapkan oleh Pondok Pesantren Al-Qohhariyah. Di antara kedisiplinan yang diterapkan kemudian dijalani oleh para santri tersebut adalah bangun tidur pada jam 04.00 pagi setiap harinya. Kedisplinan lainnya adalah dalam salat berjamaah lima waktu, mulai berjamaah untuk melaksanakan salat Subuh, Dhuhur, Ashar, Maghrib sampai dengan salat Isya berjamaah. Bahkan sebelum salat berjamaah, seluruh santri diwajibkan berkumpul di masjid 10 menit sebelum 
waktunya tiba. Apabila didapati santri yang terlambat datang ke tempat berjamaah untuk melaksanakan salat berjamaah, maka santri tersebut akan diberikan sangsi sesuai ketentuan telah berlaku.

Upaya Pondok Pesntren Al-Qohhariyah dalam mengembangkan afektif anak, juga dilakukan dengan cara memberikan kesempatan kepada santri untuk aktif dalam berbagai macam kajian. Mulanya kiyai memberikan berbagai macam kajian kitab-kitab yang telah ditetapkan, kemudian para santri dijadwalkan untuk bisa mengamalkan dan mengembangkan kajian yang telah diberikan. Di antara bentuk prakteknya adalah bahsul kutub. Dalam hal ini para santri dituntut untuk mengkaji satu kitab, kemudian santri memaparkan materi dari kitab yang telah ditentukan tersebut di hadapan para santri lainnya. Setelah uraian santri sebagai penyaji selesai, para santri lainnya diminta bertanya atau memberi tanggapan terhadap apa yang telah disampaikan. Seluruh prosesnya tetap dalam pengawasan atau kontrol kiyai.

Berdasarkan pengamatan, selain bahsul kutub, guna mengembangkan afektif anak, di Pondok Pesantren Al-Qohhariyah juga diadakan ta'limul muhadatsah atau muhadhoroh. Di dalam kegiatan tersebut terdapat berbagai macam kegiatan beserta petugasnya yang harus diisi oleh para santri itu sendiri. Di dalam muhadloroh ada sub kegiatan berpidato, tilawatil Qur'an, hadiah dzikir, menberikan sambutan dan lain lain. Masingmasing kegiatan tersebut ada petugasnya yang juga berasal dari para santri itu sendiri. Tahapan yang paling berat dan bermanfaat bagi santri adalah ketika santri mendapatkan jadwal untuk berpidato. Dalam kegiatan ini para santri secara tidak langsung belajar bagaimana cara berinteraksi dengan audience, bagaimana cara menarik perhatian audience, dan bagaimana cara bertuturkata yang baik dan benar, dan berbagai aspek lain dengan pidato. Dalam berpidato juga ada unsur keteladanan. Maka dalam hal ini santri diajarkan untuk menjadi suri tauladan. ketika santri sebelum berpidato tentang satu tema yang akan disampaikan, santri dituntut untuk melaksanakan apa yang akan disampaikannya kepada para santri. Sudah sama sama diyakini bahwa berbicara melalui tingkah laku itu lebih baik dari pada berbicara melalui ucapan.

Sebagaimana diuraikan di muka, selain tampil berpidato santri juga diberikan kesempatan untuk tilawatilqur'an, hadiah dzikir dan menjadi penata acara (MC). Masing-masing sub kegiatan tersebut ada petugasnya sendirisendiri. Setiap kali kegiatan latihan berpidato, biasanya satu orang santri ada yang mendapatkan tugas untuk berpidato, adakalanya juga para santri diberikan tugan menjadi MC, dan lain lain. Hal ini dilakukan agar santri memahami dan terlatih pengembangan afektifnya dalam berbagai hal dan keadaan.

Selama berada di Pondok Pessantren, para santri yang telah resmi menjadi santri di Pondok Pesantren Al-Qohhariyah, dituntut untuk bisa menjadi orang lebih mandiri. Sebelumnya para santri ketika berada di lingkungan rumah, menggantungkan dirinya dan bermanja-manja kepada keluarga seperti ayah, ibu, kakak dan sebagainya, maka setelah tiba di pondok Pesantren Al-Qohhariyah tersebut suasana itu seketika perlahan tapi pasti akan hilang, karena disini para santri dituntut untuk melaksanakan secara mandiri. Ketika di rumah anak dalam keadaan lapar dan membutuhkan makanan mungkin si anak tersebut tinggal meminta kepada ayah atau ibunya, tapi ketika sudah berada di lingkungan pondok Pesantren AlQohhariyah maka anak tersebut, untuk menghilangkan rasa lapar terlebih dahulu harus mengolah masakan sendiri. Ketika si anak berada di rumah terdapat pakaian kotor, yang membersihkan atau mencuci adalah ibunya. Tetapi ketika berada di Pondok Pesantren AlQohhariyah santri harus mencuci pakaiannya sendiri"

Maka disinilah kemandirian anak dan sikap afektif anak dilatih dan dikembangkan. Sikap mandiri ini bukan hanya ditanamkan di pesantren saja melainkan yang lebih penting bagaimana seorang santri bisa merealisasikan sikap disiplin setelah keluar atau lulus dari pesantren.

Setiap lembaga pendidikan tentu menginginkan lingkungan yang damai dan aman, untuk dapat menciptakan suasana tersebut tentu harus ada upaya yang dilakukan oleh lembaga pendidikan tersebut. Adapun upaya yang dilakukan oleh Pondok Pesantren 
Al-Qohhariyah, berdasar dokumen yang ada, salah satunya adalah disusunnya tata tertib yang harus ditaati oleh seluruh santri. Agar para santri dapat mematuhi tata tertib yang telah dibuat oleh Pesantren maka harus ada yang namanya sangsi. Sangsi ini dibuat guna memberikan efek jera terhadap seluruh santri yang melanggar tata tertib dan peraturan yang telah ditetapkan di Pondok Pesantren AlQohhariyah. Dengan adanya peraturan dan sangsi yang telah ditetapkan oleh Pondok Pesantren Al-Qohhariyah maka secara sadar para santri dituntut untuk selalu waspada dalam segala hal, dalam setiap kondisi dan dalam setiap waktu.

Di lingkungan pondok pesantren yang penuh dengan keramaian manusia seperti di lingkungan Pondok Pesantren Al-Qohhariyah para santri hidup saling berdampingan dengan santri yang lainnya. Hal ini menuntut santri untuk saling mengenal antara satu dengan yang lainnya, karena pada hakekatnya manusia hidup di muka bumi ini tidak bisa hidup sendiri tetapi membutuhkan bantuan dari orang lain. Manusia adalah makhluk sosial yang saling berkesinambungan antara satu dengan yang lainnya. Maka dengan ditanamkannya rasa sosial di Pondok Pesantren Al-Qohhariyah, para santri secara tidak langsung memahami berbagai macam karakter yang dimiliki oleh sesama teman santrinya. Hal ini pun tentu akan sangat berpengaruh terhadap kehidupannya kelak ketika hidup bermasyarakat di lingkungan yang lebih luas. Dalam satu masyarakat masingmasing orang memiliki karakter yang berbeda beda pula, yang lebih rumit dibandingkan dengan lingkungan pesantren yang tinggal hanya satu atap. Hal ini terjadi karena di dalam masyarakat, kebutuhan manusia lebih bersifat banyak dan luas.

Pengembangan bakat dan minat yang digalakkan di Pondok Pesantren Al-Qohhariyah juga menjadi salah satu proses pengembangan afektif anak. Di antara kegiatan pengembangan bakat tersebut adalah adanya kegiatan marawis, qosidah, hadroh, futsal dan silat. Semua kegiatan tersebut secara tidak langsung ketika para santri sedang dalam proses pelatihan, maka santri dituntut untuk sabar, melatih keseimbangan diri dan ketekunan agar hasil yang telah diinginkan oleh seorang pelatih dan yang dilatih berbuah hasil yang memuaskan.

Maka disinilah proses pengembangan afektif terhadap santri berjalan, baik disadari ataupun tidak oleh para santri. Pada dasarnya pengembangan bakat dan minat ini biasanya diikuti oleh santri berdasarkan rasa senang dan hobi, karena kegiatan tersebut merupakan kegiatan yang diminati oleh santri. Ketika proses latihan berlangsung pun para santri melakukannya dengan suka rela, tanpa ada paksaan dari pelatih atau orang lain,

Sebagai bagian dari beberapa
pengembangan bakat dan minat yang ditanamkan di Pondok Pesantren AlQohhariyah tak sedikit diantaranya mereka sering diikutsertakan dalam berbagai macam kegiatan musabaqoh atau perlombaan, baik itu perlombaan di lingkungan Pondok Pesantren Al-Qohhariyah, tingkat kecamatan, tingkat kabupaten, tingkat Jabodetabek, bahkan sampai tingkat Provinsi Jawa Barat. Hasil yang diraihpun sering kali mendapatkan prestasi yang membanggakan, dengan menjuarai kegiatan perlombaan tersebut, seperti perlombaan marawis, perlombaan qosidah, perlombaan hadroh dan perlombaan futsal di berbagai macam tingkatan dari lokal sampai nasional.

\section{PENUTUP}

Berdasarkan uraian di atas dapat disimpulkan bahwa pola asuh pendidikan Pondok Pesantren Al-Qohhariyah terwujud melalui penanaman disiplin santri, penanaman kemandirian, penanaman sikap sadar akan pentingnya bermasyarakat, pembiasaan melakukan kajian kitab, pengembangan bakat dan minat, serta pemberian sangsi terhadap santri yang melanggar tata tertib. Semuanya dimaksudkan dalam rangka mengembangkan kematangan emosi anak.

Pola asuh pendidikan pesantren terhadap perkembangan afektif anak sebagaimana yang terdapat di Pondok Pesantren Al-Qohhariyah Kabupaten Bogor telah mampu membentuk sikap dan perilaku yang membawa tabiat positif para anak dalam belajar di pesantren. Temuan ini menguatkan pendapat bahwa pondok pesantren yang tergolong lembaga pendidikan tertua di Indonesia tersebut juga sekaligus 
berperan dalam mencerdaskan kehidupan masyarakat. Pencerdasan yang terlihat pada hasil pendidikan tersebut ditanamkan secara terus menerus di bawah bimbingan para pimpinan pesantren.

Temuan ini cukup penting karena di satu pihak perhatian masyarakat dan negara terhadap pesantren semakin meningkat, yang dibuktikan dengan adanya trend meningkat jumlah dan kualitas pondok pesantren, juga adanya peningkatan landasan hukum pondok pesantren, berupa adanya Undang-Undang Nomor 18 Tahun 2019 tentang Pesantren. Namun di pihak lain, banyak pesantren yang kondisinya masih memprihatinkan karena masalah internal dan eksternalnya yang perlu memperoleh perhatian yang lebih besar baik dari pemerintah maupun masyarakat.

Adanya sejumlah keterbatasan penelitian ini, diperlukan pendalaman lebih lanjut terhadap pola asuh yang dikaitkan dengan aspek-aspek lainnya yang terkait dengan peningkatan kualitas santri atau masyarakat pesantren. Sehingga dengan demikian di masa depan diharapkan hasil pendidikan pada pesantren dapat lebih efektif, efisien, dan maksimal kebermanfaatannya bagi masyarakat. Akan lebih bermanfaat apabila di masa yang akan datang dapat dilanjutkan penelitian yang lebih luas dan mendalam lagi mengenai pola asuh pendidikan pesantren. Bukan hanya pada aspek perkembangan afektif anak, akan tetapi pada aspek-aspek penting lainnya, seperti aspek intelektualnya.

\section{DAFTAR PUSTAKA}

Azra, Azyumardi (2001) Pendidikan Islam: Tradisi dan Modernisasi Menuјu Milenium Baru. Jakarta: Logos Wacana Ilmu dan Pemikiran.

Astrea, N. (2019) Peran Teman Sebaya Dalam Perkembangan Afektif Siswa Kelas IV SDN Banyudono 1 Ngariboyo Magetan. (Doctoral dissertation, IAIN Ponorogo).

Basri, Hasan (2013) Landasan Pendidikan. Bandung: Pustaka Setia.

Bukhori, Umar (2011) Ilmu pendidikan Islam. Jakarta: Bumi Aksara.
Cialdini, Robert B. (2005) Psikologi Persuasif Merekayasa Kepatuhan. Jakarta: Kencana.

Daulay (2004) Pendidikan Islam dalam Perspektif Filsafat. Jakarta: Kencana.

Departemen Agama RI. (2003) Pondok Pesantren dan Madrasah Diniyah. Jakarta: Depag RI. Di

Dianwinarti (2012) Perkembangan afektif anak. https://diianwinarti.wordpress.com/ 2012/11/26/ perkembangan, (Dikutip tanggal 16 Mei 2020)

Gunarsa, dan Ny.Y.Singgih Singgih (19910, Psikologi Remaja. Jakarta: GunungMulia

Horton dan Hunt (1991) Sosiologi. Jakarta: Erlangga.

Hasan, Langgulung (2003) Asas-asas Pendidikan Islam. Jakarta: Pustaka AlHusna.

Madjid, Nurcholish (1983) "Merumuskan Kembali Tujuan Pendidikan Pesantren", dalam M Dawam Rahardjo (Ed): Pergulatan Dunia Pesantren, Membangun Dari Bawah. Jakarta: P3M.

Mastuhu (1994) Dinamika Sistem Pendidikan Pesantren. Jakarta: INIS.

Monty P. Satiadarma and Fidelis E. Waruwu (2003) Mendidik Kecerdasan Pedoman Bagi Orang Tua Dan Guru Dalam Mendidik Anak. Jakarta: Media Grafik.

Muhaimin dkk. (2001) Paradigma Pendidikan Islam. Upaya Mengefektifkan Pendidikan Agama Islam di Sekolah. Jakarta: PT Remaja Rosdakarya.

Nurhidayati, A., \& Sunarsih, E. S. (2013). Peningkatan Hasil Belajar Ranah Afektif melalui Pembelajaran Model Motivasional. Jurnal Ilmiah Pendidikan Teknik dan Kejuruan, 6(2).

Olivia Femi (2007) Membantu Anak Mempunyai Ingatan Super. Jakarta: PT. Gramedia.

Qowaid (2017) "Penyelenggaraan Pendidikan Agama Islam Terpadu pada Sekolah Menengah Islam Nur Hidayah Surakarta". Dialog: Jurnal Penelitian dan Kajian Keagamaan. 40 (2). 
Qowaid (2019) Diversifikasi Pondok Pesantren. Jakarta: PT Pesagimandiri Perkasa.

Rahmat, Jalaluddin (2011) Psikologi Komunikasi. Bandung: PT Remaja Rosdakarya.

Rakhmawati (2013) Pola Pengasuhan Santri di Pondok Pesantren dalam Mengantisipasi Radikalisme Jurnal Diskursus Islam Volume 1 Nomor 1, April 2013 hal 42. Tersedia pada: http://repositori.uinalauddin.ac.id/id/eprint/703 (Diakses Pada: 12 Desember 2019)

Santoso, Thomas (2002) Teori-teori Kekerasan. Jakarta: Ghalia Indonesia.

Sarwono, Wirawan Sarlito (1982) Мепијu Keluarga Bahagia. Jakarta: BatharaKarya.

Soerjono, Soekanto (1986) Sosiologi Suatu Pengantar. Jakarta: CV Rajawali.

Soekamto. (1999) Kepemimpinan Kiyai Dalam Pesantren. Jakarta: LP3ES.

Sugiyono (2011) Metode Penelitian Kuantitatif, Kualitatif dan $R \& D$. Bandung: Afabeta

Sunarti dkk. (1989) Pola Pengasuhan Anak. Jakarta: Departemen Pendidikan dan Kebudayaan
Sunarto dan Hartono, Agung (2008) Perkembangan Peserta Didik. Jakarta: Rineka Cipta.

Sunarto dan Ny. B. Agung Hartono (2008) Perkembangan Peserta Didik. Jakarta: Rineka Cipta.

Tafsir, Ahmad (2000) Ilmu Pendidikan dalam Perspektif Islam. Bandung: Remaja Rosdakarya.

Thoha, Chabib (1996) Kapita Selekta Pendidikan Islam. Yogyakarta: Pustaka Pelajar Offset.

Tilaar, H.A.R. (1999) Pendidikan, Kebudayaan, dan Masyarakat Madani Indonesia. Bandung: PT Remaja Rosdakarya.

Undang-Undang Nomor 19 Tahun 2019 Tentang Pesantren.

Wahidmurni. (2008). Penilaian Tindakan Kelas dari teori menuju Praktik. Malang: UM PRESS.

Wahid, Abdurrahman (1983) "Pesantren Sebagai Subkultur". Dalam M. Dawam Rahardjo (Ed): Pesantren dan Pembaharuan. 